\title{
PENGARUH KEPEMIMPINAN TRANSFORMASIONAL DAN TRANSAKSIONAL TERHADAP IKLIM ORGANISASI DAN ORGANIZATIONAL CITIZENSHIP BEHAVIOR
} (Studi Pada RSUD Genteng Kabupaten Banyuwangi)

Moh. In'am Latif

Fakultas Ekonomi dan Bisnis, Universitas Brawijaya e-mail: inamlatif@gmail.com

\begin{abstract}
The purpose of this study aims to analyzes how much influence transformational leadership (X1) and transactional leadership (X2) to organizational climate (Z) and organizational citizenship behavior (Y) at RSUD Genteng Kabupaten Banyuwangi. This research used a quantitative approach with Partial Least Square. As for the number of samples as many 130 respondents taken by using Proportional Random Sampling method. The results of this study whole that transformational leadership and transactional leadership have a significant effect on organizational climate. Transformational leadership and transactional leadership have a significant effect on organizational citizenship behavior, either directly or indirectly through organizational climate. Based on the results of this study, the management of hospitals need to develop what has been a common perception and understanding between the leadership with employees, by innovating in terms of policy leaders, both for the organization as a whole or required for employees.
\end{abstract}

Keywords: Organizational Citizenship Behavior, Organizational Climate, Transformational Leadership, Transactional Leadership

\begin{abstract}
Abstrak : Tujuan penelitian ini adalah untuk menganalisis seberapa besar pengaruh kepemimpinan transformasional (X1) dan kepemimpinan transaksional (X2) terhadap iklim organisasi (Z) dan perilaku kewargaan organisasional (Y) di RSUD Genteng Kabupaten Banyuwangi. Penelitian ini menggunakan pendekatan kuantitatif dengan Partial Least Square. Adapun untuk jumlah sampel yang digunakan adalah sebanyak 130 responden diambil dengan menggunakan metode Proportional Random Sampling. Hasil penelitian ini keseluruhan bahwa kepemimpinan transformasional dan kepemimpinan transaksional memiliki pengaruh yang signifikan terhadap iklim organisasi. Kepemimpinan transformasional dan kepemimpinan transaksional memiliki pengaruh yang signifikan terhadap perilaku warga organisasi, baik secara langsung maupun tidak langsung melalui iklim organisasi. Berdasarkan hasil penelitian ini, manajemen rumah sakit perlu mengembangkan apa yang telah menjadi persepsi umum dan pemahaman antara kepemimpinan dengan karyawan, dengan berinovasi dalam hal pemimpin kebijakan, baik untuk organisasi secara keseluruhan atau diperlukan untuk karyawan.
\end{abstract}

Kata Kunci : Iklim Organisasi, Kepemimpinan Transformasional, Kepemimpinan Transaksional, Organizational Citizenship Behavior 


\section{PENDAHULUAN}

\section{Latar Belakang}

Manusia merupakan motor penggerak sumber daya yang ada dalam rangka aktifitas dan rutinitas dari sebuah organisasi atau perusahaan. Sebagaimana diketahui sebuah organisasi atau perusahaan, didalamnya terdiri dari berbagai macam individu yang tergolong dari berbagai status yang mana status tersebut berupa pendidikan, jabatan dan golongan, pengalaman, jenis kelamin, status perkawinan, tingkat pengeluaran, serta tingkat usia dari masing - masing individu tersebut (Hasibuan, 2000).

Kehidupan dalam sebuah organsisasi, dalam hal ini adalah pimpinan merupakan peran yang amat penting, bahkan dapat dikatakan sangat menentukan, dalam usaha pencapaian tujuan yang telah ditetapkan sebelumnya. Untuk melaksanakan tugas sebagai seorang pimpinan ia harus membagi-bagi tugas dan pekerjaan tersebut kepada seluruh pagawai yang ada dalam unit kerjanya sesuai hierarkhi. Seorang pimpinan harus mampu menciptakan suasana yang kondusif, memberikan cukup perhatian, memberikan penghargaan terhadap prestasi kerja, menjalin komunikasi yang baik dengan seluruh pegawai. Untuk menciptakan kondisi demikian, diperlukan adanya usaha-usaha untuk meningkatkan kualitas iklim organisasi yang ada, mengoptimalkan peran pegawai dan perilaku ekstra peran pegawai. Ini dimungkinkan bila terwujudnya pemimpin yang baik dan bekerja secara optimal. Sebab bagaimanapun juga tujuan organisasi/perusahaan, salah satunya adalah untuk meningkatkan kesejahteraan.

Rumah sakit merupakan organisasi pelayanan jasa yang mempunyai kespesifikan dalam hal SDM, sarana prasarana dan peralatan yang dipakai. Sering rumah sakit dikatakan sebagai organisasi yang padat modal, padat sumber daya manusia, padat tehnologi dan ilmu pengetahuan serta padat regulasi. Padat modal karena rumah sakit memerlukan investasi yang tinggi untuk memenuhi persyaratan yang ada. Padat sumberdaya manusia karena didalam rumah sakit pasti terdapat berbagai profesi dan jumlah karyawan yang banyak. Padat tehnologi dan ilmu pengetahuan karena di dalam rumah sakit terdapat peralatan-peralatan canggih dan mahal serta kebutuhan berbagai disiplin ilmu yang berkembang dengan cepat. Padat regulasi karena banyak regulasi/peraturan-peraturan yang mengikat berkenaan dengan syarat-syarat pelaksanaan pelayanan di rumah sakit.

$$
\text { RSUD Genteng Kabupaten }
$$

Banyuwangi merupakan organisasi usaha dibidang pelayanan kesehatan di bawah naungan Dinas Kesehatan Pemerintah Daerah Kabupaten Banyuwangi, yang terus melakukan perbaikan disegala bidang menuju profesionalisme usaha. Konsep profesionalisme layanan ini terlebih dahulu perlu dievaluasi kinerja karyawannya, dalam kaitan dengan perubahan tersebut (Hastuti, 2003). Pada aktivitas sehari-hari RSUD Genteng Banyuwangi masih terlihat adanya OCB karyawan yang rendah. Hal ini diungkapkan oleh Kepala Bagian Personalia RSUD Genteng. Tidak dipungkiri keluhan klasik bagi RS Pemerintah adalah kurang ramahnya pegawai Rumah Sakit, demikian juga di RSUD Genteng Banyuwangi. Tidak dipungkiri keluhan klasik bagi rumah sakit pemerintah adalah kurang ramahnya pegawai rumah sakit, demikian juga di RSUD Genteng Banyuwangi. Hal ini perlu dikaji latar belakangnya, input sumber daya manusia yang memang berwatak demikian, adanya persepsi bahwa pasien adalah beban pekerjaan baginya, tanpa mengingat bahwa pasien sebenarnya merupakan "uang" baginya, atau proses pelaksanaan pelayanan yang melelahkan fisik dan mental, karena sikap pasien yang menjengkelkan, dan lain-lain. Dalam usaha pencapaian tujuan organisasi yang telah ditetapkan sebelumnya tugas pimpinanlah untuk memberdayakan semua sumber-sumber yang ada didalam organisasi, terutama sumber daya manusianya melalui iklim organisasi. Namun yang menjadi permasalahan pada RSUD Genteng Banyuwangi saat ini, yaitu wewenang pimpinan yang begitu dominan terhadap masalah-masalah sumber daya manusia, keuangan serta pengembangan lainnya. Hal ini akan menimbulkan sikap apatis, tidak bersemangat, ragu-ragu dan takut salah, kecewa, masa bodoh, putus asa, menjadikan kegiatan yang ada tidak berjalan sebagaimana mestinya sehingga menyebabkan perilaku ekstra peran pegawai yang rendah.

\section{Rumusan Masalah}

Pada RSUD Genteng Kabupaten Banyuwangi terdapat berbagai permasalahan yang muncul pada karyawannya yang berkaitan dengan Organizational Citizenship Behavior (OCB) adalah sering mencuri waktu untuk istirahat pada jam kerja, terlambat kerja setelah 
waktu istirahat dan mengulur waktu dalam penyelesaian pekerjaan, kurangnya partisipasi karyawan dalam kegiatan karyawan di luar jam kerjam kurang dapat bekerja sama dengan karyawan lainnya, individualis dalam penyelesaian pekerjaan, kurang komunikatif dengan rekan kerjanya dan kurangnya perhatian kepada pasien. Berdasarkan permasalahan tersebut, maka pertanyaan yang diajukan dalam penelitian ini adalah :

1. Apakah kepemimpinan transformasional berpengaruh terhadap iklim organisasi?

2. Apakah kepemimpinan transaksional berpengaruh terhadap iklim organisasi?

3. Apakah kepemimpinan transformasional berpengaruh terhadap Organizational Citizenship Behavior?

4. Apakah kepemimpinan transaksional berpengaruh terhadap Organizational Citizenship Behavior?

5. Apakah iklim organisasi berpengaruh terhadap Organizational Citizenship Behavior?

6. Apakah kepemimpinan transformasional berpengaruh terhadap Organizational Citizenship Behavior melalui variabel iklim organisasi?

7. Apakah kepemimpinan transaksional berpengaruh terhadap Organizational Citizenship Behavior melalui variabel iklim organisasi?

\section{Kepemimpinan Transformasional}

Menurut Bass (1985) dalam buku Yukl

(2013, p.313) menjelaskan bahwa kepemimpinan transformasional adalah suatu keadaan dimana para pengikut dari seorang pemimpin transformasional merasa adanya kepercayaan, kekaguman, kesetiaan, dan hormat terhadap pemimpin tersebut, dan mereka termotivasi untuk melakukan lebih dari pada yang awalnya diharapkan mereka. Menurut Bass dalam Robbins dan Judge (2007, p.387) kepemimpinan transformasional adalah pemimpin yang memberikan pertimbangan dan rangsangan intelektual yang diindividualkan dan memiliki kharisma. Sedangkan menurut Newstrom dan Bass (dalam Sadeghi dan Pihie, 2012) pemimpin transformasional memiliki beberapa komponen perilaku tertentu, diantaranya adalah integritas dan keadilan, menetapkan tujuan yang jelas, memiliki harapan yang tinggi, memberikan dukungan dan pengakuan, membangkitkan emosi pengikut, dan membuat orang untuk melihat suatu hal melampui kepentingan dirinya sendiri untuk meraih suatu hal yang mustahil. Tucker dan Lewis (2004:78) mendefinisikan kepemimpinan transformasional sebagai pola kepemimpinan yang dapat memotivasi karyawan dengan cara membawa pada cita-cita dan nilai-nilai tinggi untuk mencapai visi misi organisasi yang merupakan dasar untuk membentuk kepercayaan terhadap pimpinan.

Dari pendapat diatas maka dapat disimpulkan bahwa kepemimpinan transformasional merupakan pemimpin yang kharismatik dan mempunyai peran sentral serta strategi dalam membawa organisasi mencapai tujuannya. Pemimpin transformasional juga harus mempunyai kemampuan untuk menyamakan visi masa depan dengan bawahannya, serta mempertinggi kebutuhan bawahan pada tingkat yang lebih tinggi dari pada apa yang mereka butuhkan. Interaksi yang timbul antara pemimpin dengan bawahannya ditandai dengan pengaruh pemimpin untuk mengubah perilaku bawahannya menjadi seorang yang merasa mampu dan bermotivasi tinggi dan berupaya mencapai prestasi kerja yang tinggi dan bermutu.

Kepemimpinan transformasional dikonseptualisasikan dalam empat komponen atau karakteristik yang terpisah (Krishnan, 2005, B. Fortman, 2005):

1) Idealized Influence (Pengaruh Ideal)

Idealized influence adalah perilaku pemimpin yang memberikan visi dan misi, memunculkan rasa bangga, serta mendapatkan respek dan kepercayaan bawahan.

2) Inspirational Motivation (Motivasi Inspirasional)

Inspirational motivation adalah perilaku pemimpin yang mampu mengkomunikasikan harapan yang tinggi, menyampaikan visi bersama secara menarik dengan menggunakan simbol-simbol untuk memfokuskan upaya bawahan, dan menginspirasi bawahan untuk mencapai tujuan yang menghasilkan kemajuan penting bagi organisasi.

3) Intellectual Stimulation (Stimulasi Intelektual)

Intellectual stimulation adalah perilaku pemimpin yang mampu meningkatkan kecerdasan bawahan untuk meningkatkan kreativitas dan inovasi mereka, meningkatkan rasionalitas, dan pemecahan masalah secara cermat.

4) Individualized Consideration (Pertimbangan Individual) 
Individualized consideration adalah perilaku pemimpin yang memberikan perhatian pribadi, memperlakukan masing-masing bawahan secara individual sebagai seorang individu dengan kebutuhan, kemampuan, dan aspirasi yang berbeda, serta melatih dan memberikan saran.

\section{Kepemimpinan Transaksional}

Kepemimpinan transaksional dikonseptualisasikan sebagai proses pertukaran biaya manfaat antara pemimpin dan pengikut Arons (2006). Pemimpin dan pengikut bertindak pelaku tawar - menawar dala suatu proses pertukaran yang melibatkan imbalan dan hukuman. Ide utama pendekatan transaksional adalah adanya satu pertukaran, pemimpin menginginkan apa yang dimiliki pengikut dan sebagai balasan pemimpin akan memberikan apa yang diinginkan oleh pengikut. Dengan demikian, pemimpin transaksional memotivasi bawahan untuk bertindak sesuai dengan yang diharapkan melalui koreksi, kemudian penetapan imbalan dan hukuman.

Kepemimpinan transaksional memiliki dua dimensi yang meliputi: (Bass 1995, 1997 dalam Brown, 2003; Fortman, 2005:5):

1. Contingent rewards: pemimpin melakukan kontrak pertukaran imbalan untuk upaya yang dilakukan, menjanjikan imbalan bagi kinerja yang baik, menghargai orestasi kerja.

2. Management by exeptions:

- Aktif: pemimpin mengawasi dan mencari penyimpangan atas berbagai aturan dan standar, serta mengambil tindakan korektif.

- Pasif: pemimpin melakukan intervensi hanya bila standar tidak tercapai

Dengan demikian dapat disimpulkan bahwa pemimpin transaksional berusaha: (1) memahami apa yang diinginkan bawahan dari pekerjaan mereka dan meyakinkan bahwa para bawahan menerima balasan bila kinerja mereka sesuai dengan standar, (2) menjanjikan dan memberikan imbalan mereka atas usaha bawahan, (3) mengakomodasi kepentingan pribadi bawahan bila mereka dapat menyelesaikan tugas.

\section{Iklim Organisasi}

Iklim organisasi secara objektif eksis, terjadi di setiap organisasi, dan mempengaruhi perilaku anggota organisasi, tetapi hanya dapat di ukur secara tidak langsung melalui persepsi anggota organisasi. Dimensi iklim organisasi adalah unsur, faktor, sifat atau karakteristik variabel iklim organisasi. Studi yang dilakukan oleh para pakar iklim organisasi menunjukkan paling tidak 460 jenis lingkungan kerja dengan iklim organisasinya sendiri-sendiri (Wirawan, 2007). Litwin \& Stringer dalam Sergiovani \& Starrat (1979) mengatakan bahwa iklim organisasi (organizational climate) sebagai akibat dari sistem formal, gaya kepemimpinan dan faktor yang berhubungan dengan lingkungan penting lainnya terhadap sikap, kepercayaan, nilai-nilai dan motivasi dari manusia yang bekerja dalam suatu organisasi. Dan pandangan Gibson et. Al. (1998) mengatakan bahwa iklim organisasi diartikan sebagai seperangkat sifat-sifat lingkungan kerja yang dirasaka baik langsung mapun tidak langsung oleh pegawai, dan diduga berpengaruh terhadap perilaku kerjanya.

Iklim tidak dapat dilihat dan disentuh, tapi iklim ada dan dapat dirasakan. Iklim dipengaruhi oleh hampir semua hal yang terjadi dalam suatu organisasi. Jika sebuah organisasi ingin berhasil dalam mewujudkan cita-cita dan tujuannya secara utuh dan sempurna, maka dibutuhkan individu-individu yang handal sebagai sumber daya yang akan memegang kendali tali organisasi. Agar Sumber Daya Manusia di dalam organisasi dapat bekerja secara optimal dan memiliki loyalitas yang tinggi, maka organisasi harus dapat menciptakan iklim yang baik dan menyenangkan. Sehingga sumber daya manusia yang telah terbentuk kualitasnya dapat terus dipertahankan dan mereka memiliki disiplin serta prestasi kerja yang tinggi.

Teori Iklim organisasi yang digunakan dalam penelitian ini berdasarkan teori Litwin \& Stringer (1986) yang dijabarkan atau diukur melalui lima dimensi iklim organisasi, yaitu:

a. Tanggung Jawab

Tanggung jawab (responsibility) adalah perasaan menjadi pimpinan bagi diri sendiri, tidak selalu harus mengecek ulang semua keputusan yang diambil, ketika karyawan mendapat suatu pekerjaan, karyawan yang bersangkutan mengetahui bahwa itu adalah pekerjaannya. Karyawan akan merasa senang menerima tanggung jawab yang diberikan atasannya, karena selain mendapat kejelasan mengenai batasan-batasan tugas yang diterimanya serta kepada siapa dia harus mempertanggung jawabkan hasil kerjanya, karyawan termotivasi untuk menerima tanggung jawab lain dan menyelesaikan tugas yang diterimanya dengan baik. 
b. Identitas

Identitas (identity) adalah perasaaan memiliki (sense of belonging) terhadap perusahaan dan diterima dalam kelompok.

c. Kehangatan

Kehangatan (warmth) adalah perasaan terhadap suasana kerja yang bersahabat dan lebih ditekankan pada kondisi keramahan atau persahabatan dalam kelompok yang informal, serta hubungan yang baik antar rekan kerja, penekanan pada pengaruh persahabatan dan kelompok sosial yang informal.

d. Dukungan

Dukungan (support) adalah hal-hal yang terkait dengan dukungan dan hubungan antar sesama rekan kerja yaitu perasaan saling menolong antara manajer dan karyawan, lebih ditekankan pada dukungan yang saling membutuhkan antara atasan dan bawahan.

e. Konflik

Konflik (conflict) merupakan situasi terjadi pertentangan atau perbedaan pendapat antara bawahan dengan pimpinan dan bawahan dengan bawahan. Ditekankan pada kondisi dimana manajer dan para pekerja mau mendengarkan pendapat yang berbeda. Kedua belah pihak bersedia menempatan masalah secara terbuka dan mencari solusinya daripada menghindarinya.

\section{Organizational Citizenship Behavior (OCB)}

Terdapat beberapa terminologi untuk menyebutkan OCB diantaranya adalah good citizenship behavior, good soldier syndrome, extra-role behavior dan prosocial behavior. Namun demikian semuanya mengarah pada suatu pengertian yang sama yaitu perilaku sukarela, yang tidak terkait, baik secara langsung atau eksplisit, dengan sistem imbalan formal, dan secara agregat mendorong efektivitas organisasi (Organ, 1988 dalam Farrel dan Finkelstein, 2007). OCB merujuk pada kontribusi seseorang pada organisasi yang melebihi tugas dan imbalan yang telah diitetapkan (in-role behavior) dan merupakan salah satu bentuk periaku prososial, yaitu perilaku yang bersifat positif, konstruktif, dan "helpfull".

Perilaku extra-role ini merupakan nila tambahan bagi karyawan yang tidak dimasukkan dalam pengukuran kinerja secara tradisional. Perbedaan antara in-role dan extra role terletak pada sistem pemberian imbalan formal. Kinerja in-role behavior dapat diukur dan dihubungkan dengan sistem imbalan formal (sanksi dan balas jasa), adapaun extra role behavior merupakan perilaku sukarela dimana pelakunya tidak mendapatkan kompensasi.

OCB merupakan konsep multidimensional, yang terdiri dari beberapa dimensi, antara lain: Organ (1988) dalam (Farrel dan Finkelstein, 2007).

a. Altruism: perilaku suka menolong orang lain tanpa pamrih,

b. Conscientiousness: melaksanakan tugas/kewajiban melebihi ketentuan minimal,

c. Sportmanship: toleransi (tidak selalu mengeluh) terhadap kondisi yang tidak diharapkan,

d. Courtessy: mempertimbangkan dampak yang akan menimpa pihak lain sebelum megambil keputusan,

e. Civic virtue: terlibat dalam fungsi-fungsi organisasi.

Ada beberapa faktor yang mempengaruhi OCB, studi yang dilakukan oleh Smith, Organ dan Near (2003) dalam Dick et.al (2007), menunjukkan OCB memiliki beberapa anteseden diantaranya adalah: persepsi terhadap keadilan organisasional, kepuasan kerja, gaya kepemimpinan dan komitmen organisasional. Variabel variabel tersebut berpengaruh positif terhadap OCB.

Persamaan penelitian terdahulu dengan penelitian sekarang adalah adanya variabelvariabel yang digunakan pada penelitian terdahulu yang digunakan kembali pada penelitian, sedangkan perbedaannya adalah objek penelitian, dan penggunaan alat analisis.

\section{Pengaruh kepemimpinan transformasional terhadap iklim organisasi \\ Pengaruh kewibawaan pemimpin} terhadap iklim organisasi ditemukan dalam beberapa penelitian yang dilakukan oleh Imran (2011), Lee (2013) dan Yildiz (2014), dan Lopez (2013). Hasil penelitian menunjukkan bahwa kewibawaan pemimpin berepngaruh signifikan terhadap iklim organisasi. Berdasarkan temuan dari penelitian-penelitian tersebut dapat dikemukakan bahwa kepemimpinan transformasional memiliki korelasi yang erat dengan iklim organisasi. Oleh karena itu perlu perlu di uji apakah kepemimpinan transformasional memiliki pengaruh terhadap iklim organisasi, dengan merumuskan hipotesis sebagai berikut: 


\section{Pengaruh kepemimpinan transaksional terhadap iklim organisasi}

Kepemimpinan transaksional

dikonseptualisasikan sebagai proses pertukaran biaya - manfaat antara pemimpin dan pengikut Arons (2006: 1163). Iklim organisasi yang kondusif terjadi karena adanya kesepakatan kontingensi reward antara pemimpin dengan pengikut atau karyawan. Sejalan dengan hal tersebut, penelitian yang dilakukan oleh Koene (2002), Walumbwa (2008), dan Suharnomo (2010) menyatakan bahwa kepemimpinan transaksional memiliki kontribusi terhadap iklim organisasi. Berdasarkan telaah teori dan penelitian tersebut, maka disusun hipotesis sebagai berikut :

\section{Pengaruh kepemimpinan transformasional terhadap organizational citizenship behavior}

Beberapa telaah empirik yang telah dilakukan, ditemukan adanya hubungan yang positif antara kepemimpinan transformasional dan organizational citizenship behavior. Pada penelitian Podsakoff et al., (1990 dalam Utomo, 2001) menyatakan bahwa "perilaku kepemimpinan mempengaruhi bawahan untuk menghasilkan kinerja melebihi apa yang seharusnya atau melebihi level minimum yang dipersyaratkan organisasi". Penelitian yang dilakukan oleh Cho (2010), Lamidi (2008), Rahmi (2013) dan Sabran (2008) tentang pengaruh kepemimpin transformasional terhadap organizational citizenship behavior. Hasil penelitian menunjukkan bahwa kepemimpinan transformasional memiliki pengaruh yang signifikan terhadap organizational citizenship behavior. Berdasarkan temuan dari penelitian-penelitian tersebut dapat dikemukakan bahwa kepemimpinan transformasional memiliki korelasi yang erat dengan organizational citizenship behavior. Oleh karena itu perlu perlu di uji apakah kepemimpinan transformasional memberikan pengaruh terhadap organizational citizenship behavior, dengan merumuskan hipotesis sebagai berikut:

\section{Pengaruh kepemimpinan transaksional terhadap organizational citizenship behavior}

Beberapa telaah empirik yang telah dilakukan, ditemukan adanya hubungan yang positif antara kepemimpinan transaksional dan organizational citizenship behavior. Penelitian yang dilakukan oleh Walumbwa (2008), Suharnomo (2010) dan Lembono (2013) tentang pengaruh kepemimpin transaksional terhadap organizational citizenship behavior. Hasil penelitian menunjukkan bahwa kepemimpinan transaksional memiliki pengaruh yang signifikan terhadap organizational citizenship behavior. Berdasarkan temuan dari penelitianpenelitian tersebut dapat dikemukakan bahwa kepemimpinan transaksional memiliki korelasi yang erat dengan organizational citizenship behavior. Oleh karena itu perlu perlu di uji apakah kepemimpinan transaksional memberikan pengaruh terhadap organizational citizenship behavior, dengan merumuskan hipotesis sebagai berikut:

\section{Pengaruh iklim organisasi terhadap organizational citizenship behavior}

Iklim organisasi akan berdampak positif jika iklim organisasi memenuhi perasaan dan kebutuhan pegawai. Iklim ditentukan oleh seberapa baik anggota diarahkan, dibangun dan dihargai oleh organisasi sehingga membentuk pola perilaku positif, antara lain OCB (Prihatsanti: 2010). Penelitian yang sama juga dilakukan oleh Prihatsanti (2010) dan Waspodo (2012), menyatakan bahwa semakin baik persepsi iklim organisasi oleh karyawan maka semakin baik pula perilaku ekstra peran karyawan di dalam suatu organisasi. Berdasarkan temuan dari penelitian-penelitian tersebut dapat dikemukakan bahwa iklim organisasi memiliki hubungan yang erat dengan organizational citizenship behavior. Oleh karena itu perlu di uji apakah iklim organisasi memberikan pengaruh terhadap organizational citizenship behavior, dengan merumuskan hipotesis sebagai berikut:

\section{Pengaruh kepemimpinan transformasional terhadap organizational citizenship behavior melalui iklim organisasi}

Kepemimpinan transformasional merupakan salah satu jenis kepemimpinan yang dalam pelaksanaannya pemimpin banyak memberikan inspirasi dan dukungan kepada para karyawan untuk lebih berkembang demi pencapaian tujuan organisasi. Penelitian yang dilakukan oleh Ngadiman (2013) dan Lee (2013) memberikan kesimpulan bahwa ada beberapa variabel yang secara tidak langsung OCB dipengaruhi oleh kepemimpinan transformasional yang salah satunya adalah iklim organisasi. Berdasarkan temuan dari penelitian-penelitian tersebut dapat dikemukakan bahwa kepemimpinan 
transformasional memiliki hubungan yang positif terhadap organizational citizenship behavior melalui iklim organisasi. Oleh karena itu perlu di uji apakah kepemimpinan transformasional memiliki hubungan yang erat dengan organizational citizenship behavior melalui iklim organisasi, dengan merumuskan hipotesis sebagai berikut:

\section{Pengaruh kepemimpinan transaksional terhadap organizational citizenship behavior melalui iklim organisasi}

Beberapa telaah empirik yang dilakukan oleh Koene (2002), Walumbwa (2008), dan Utomo (2001) ditemukan adanya pengaruh yang positif dan signifikan bahwa kepemimpinan transaksional memiliki pengaruh secara tidak langsung terhadap organizational citizenship behavior melalui iklim organisasi. Berdasarkan temuan dari penelitian-penelitian tersebut dapat dikemukakan bahwa kepemimpinan transaksional memiliki hubungan yang positif terhadap organizational citizenship behavior melalui iklim organisasi. Oleh karena itu perlu di uji apakah kepemimpinan transformasional memiliki hubungan yang erat dengan organizational citizenship behavior melalui iklim organisasi, dengan merumuskan hipotesis sebagai berikut:

H1 : Kepemimpinan transformasional berepengaruh signifikan terhadap iklim organisasi

H2 : Kepemimpinan transaksional berepengaruh signifikan terhadap iklim organisasi

H3 : Kepemimpinan transformasional berepengaruh signifikan terhadap organizational citizenship behavior

H4 : Kepemimpinan transaksional berepengaruh signifikan terhadap organizational citizenship behavior

H5 : iklim organisasi berepengaruh signifikan terhadap organizational citizenship behavior

H6 : Kepemimpinan transformasional berepengaruh signifikan terhadap organizational citizenship behavior melalui iklim organisasi

H7 : Kepemimpinan transaksional berepengaruh signifikan terhadap organizational citizenship behavior melalui iklim organisasi

\section{METODOLOGI PENELITIAN \\ Instrumen Penelitian}

Pengumpulan data dilakukan dengan menggunakan kuesioner yaitu suatu metode pengumpulan data dengan memberikan daftar pertanyaan kepada responden. Setiap responden diminta pendapatnya dengan memberikan jawaban dari pernyataan-pernyataan yang diajukan. Data dikumpulkan dengan menggunakan pertanyaan tertutup. Pertanyaan tertutup yaitu dengan mengajukan pernyataanpernyataan dalam kuesioner yang dibuat dengan menggunakan skala $1 \mathrm{~s} / \mathrm{d} 5$ untuk memperoleh data dan diberi skor atau nilai, untuk kategori pernyataan dengan jawaban sangat tidak setuju / sangat setuju:

$\begin{array}{lll}\text { STS } & : \text { Sangat Tidak Setuju } & =\text { Skor } 1 \\ \text { TS } & : \text { Tidak Setuju } & =\text { Skor } 2 \\ \text { N } & : \text { Netral } & =\text { Skor } 3 \\ \text { S } & : \text { Setuju } & =\text { Skor } 4 \\ \text { SS } & : \text { Sangat Setuju } & =\text { Skor } 5\end{array}$

\section{Populasi dan Sampel}

Populasi dalam penelitian ini adalah pegawai medis dan para medis yang bukan unsur dari pimpinan sejumlah 199 orang.

\begin{tabular}{lcc}
\multicolumn{3}{c}{ Jumlah Personalia RSUD Genteng Tahun } \\
& $\mathbf{2 0 1 6}$ & \\
\hline \multicolumn{1}{c}{ Bidang } & Frekuensi & Persentase (\%) \\
\hline Pelayanan Medis & 28 & $14 \%$ \\
Penunjang Medis & 51 & $26 \%$ \\
Keperawatan & 82 & $41 \%$ \\
Kesekretariatan & 31 & $16 \%$ \\
Keuangan & 7 & $3 \%$ \\
\hline Jumlah & $\mathbf{1 9 9}$ & $\mathbf{1 0 0 \%}$
\end{tabular}

Data Sekunder RSUD Genteng 2016

Teknik pengambilan sampel menggunakan Proportional Random Sampling, yaitu teknik pengambilan sampel secara acak dengan jumlah yang proporsional untuk masing-masing sub populasi. Adapun jumlah sampel yang digunakan dalam penelitian ini tersaji pada tabel 3 di bawah ini: Jumlah Populasi dan Sampel

\begin{tabular}{lcc}
\multicolumn{1}{c}{ Bidang } & Populasi & Sampel \\
\hline Pelayanan Medis & 28 & 19 \\
Penunjang Medis & 51 & 34 \\
Keperawatan & 82 & 55 \\
Kesekretariatan & 31 & 21 \\
Keuangan & 7 & 4 \\
\hline \multicolumn{1}{c}{ Jumlah } & $\mathbf{1 9 9}$ & $\mathbf{1 3 3}$ \\
\hline
\end{tabular}

Sumber : data diolah 
Teknik Analisis Data

\section{Metode PLS (Partial Least Square)}

Dalam penelitian ini analisis data menggunakan pendekatan Partial Least Square (PLS). PLS adalah model persamaan Structural Equation Modeling (SEM) yang berbasis komponen atau varian. Menurut Ghozali (2006), PLS merupakan pendekatan alternatif yang bergeser dari pendekatan SEM berbasis kovarian menjadi berbasis varian. Teknik pengolahan data dengan menggunakan metode SEM berbasis Partial Least Square (PLS). Software PLS pada penelitian ini menggunakan software yang dikembangkan di University of Hamburg Jerman yang diberi nama SMARTPLS versi $2.0 \mathrm{M} 3$.

\section{Model Pengukuran / Outer Model}

Agar regresi yang dihasilkan dapat memenuhi syarat sebagai best linier unbiased estimator (BLUE), maka regresi perlu diuji dengan dasar asumsi klasik metode kuadran kecil (OLS /Ordinary Least Square). Metode regresi dikatakan BLUE apabila tidak terdapat multikolinearitas, heteroskedastisitas dan autokoreasi.

\begin{tabular}{|c|c|c|}
\hline \multicolumn{3}{|c|}{$\begin{array}{c}\text { Parameter Uji Validitas dan reliabilitas } \\
\text { dalam Model Pengukuran PLS }\end{array}$} \\
\hline Pengujian & Paramater & Rute of Thumb \\
\hline \multirow{3}{*}{$\begin{array}{l}\text { Uji validitas } \\
\text { konvergen }\end{array}$} & Outer loading & Lebih dari 0,7 \\
\hline & $\begin{array}{l}\text { Average variance } \\
\text { extracted }\end{array}$ & Lebih dari 0,5 \\
\hline & Communality & Lebih dari 0,5 \\
\hline \multirow{2}{*}{$\begin{array}{l}\text { Uji validitas } \\
\text { diskriminan }\end{array}$} & $\begin{array}{l}\text { Akar AVE dan } \\
\text { korelasi variabel } \\
\text { laten }\end{array}$ & $\begin{array}{l}\text { Akar AVE }> \\
\text { korelasi variabel } \\
\text { laten }\end{array}$ \\
\hline & Cross loading & $\begin{array}{l}\text { Lebih dari } 0,7 \\
\text { dalam satu } \\
\text { variabel }\end{array}$ \\
\hline \multirow{2}{*}{$\begin{array}{l}\text { Uji } \\
\text { reliabilitas }\end{array}$} & Cronbach alpha & Lebih dari 0,6 \\
\hline & Composite reliability & Lebih dari 0,6 \\
\hline
\end{tabular}

Sumber : Chin (1995) dalam Hartono dan Abdillah (2009)

\section{Model Struktural / Inner Model}

Inner model merupakan model struktural untuk memprediksi hubungan kualitas antar variabel laten (Hartono dan Abdillah, 2009). Model struktural PLS diuji dengan mengukur nilai $\mathrm{R}^{2}$ dan koefisien path melalui perbandingan $t$-statistic dengan $t$-table pada output smartPLS. Berikut adalah parameter pengukuran inner model dalam PLS yang digunakan dalam penelitian ini adalah :

1. $\mathrm{R}^{2}$ (R-Square)
Nilai $\mathrm{R}^{2}$ digunakan untuk mengukur tingkat variasi perubahan variabel eksogen terhadap variabel endogen. Nilai $R^{2}$ menggambarkan seberapa besar variabel laten endogen dapat dipengaruhi oleh perubahan variabel eksogennya.

2. Koefisien path

Nilai koefisien path menunjukkan tingkat signifikansi dalam pengajuan hipotesis. Skor koefisien path dijelaskan melalui nilai $t$ statistic akan dibandingkan dengan nilai $t$ table dalam pengajuan hipotesis.

\section{HASIL DAN PEMBAHASAN \\ Deskripsi Obyek Penelitian}

Rumah Sakit Umum Daerah Genteng (RSUD Genteng) semula adalah rawat inap dari Puskesmas Genteng Kulon, kemudian pada tahun 1981 terpisah dan berdiri sendiri menjadi Rumah Sakit Umum Daerah Genteng, sedangkan pelayanan rawat jalan puskesmas tetap ada sampai sekarang. Berdasarkan Peraturan Daerah Kabupaten Banyuwangi No.6 tahun 1984 tanggal 20 Juni 1984 Tentang Organisasi Perangkat Daerah Kabupaten Banyuwangi dan Keputusan Gubernur KDH TK. I Jawa Timur tanggal 12 Oktober 1984 No. 338/ P tahun 1984 Tentang Pembentukan Organisasi dan Tata Kerja Rumah Sakit Umum Daerah Kelas D, secara resmi Rumah Sakit Umum Daerah Genteng telah disahkan menjadi Rumah Sakit kelas D. Kemudian berdasarkan Keputusan Menteri Kesehatan Republik Indonesia No :168 / MENKES /II / 1994 tanggal 3 Maret 1994 Tentang Prekursor Farmasi, Rumah Sakit Umum Genteng ditingkatkan statusnya menjadi Rumah Sakit kelas C. Ditindaklanjuti dengan Surat Keputusan Bupati No : 188/1561/KEP/429.011/2011 Tanggal 30 Desember 2011 Tentang Penetapan Penerapan Rumah Sakit Umum Daerah, bahwa Rumah Sakit Umum Daerah Genteng ditetapkan sebagai Badan Layanan Umum Daerah (BLUD) penuh sampai dengan sekarang.

\section{Validitas dan Reliabilitas Instrumen Penelitian}

Berdasarkan Tabel 5.4, hasil pengujian validitas yang dilakukan untuk seluruh variabel menunjukkan bahwa hasil yang valid dengan signifikansi nilai korelasi Pearson lebih kecil dari 5\% dan nilai Item Total Correlation untuk setiap indikator lebih besar dari 0,3 .

Selain validitas, suatu instrumen diharapkan memiliki stabilitas dan konsistensi 
dalam mengukur suatu konstruk sehingga instrumen perlu dilakukan pengujian reliabilitas (Sekaran, 1992). Pengujian reliabilitas dilakukan dengan model Alpha dan tingkat kepercayaan 95\% two-tailed. Suatu konstruk dikatakan reliabel jika koefisien Cronbach Alpha lebih besar dari 0,7, tetapi nilai tersebut dapat diturun menjadi lebih besar dari 0,6 untuk penelitian yang bersifat eksploratory. Berdasarkan tabel 5.4, hasil pengujian reliabilitas menunjukkan bahwa semua variabel penelitian memiliki nilai cronbach's alpha di atas 0,6 , sehingga semua variabel disimpulkan reliabel.

\section{Analisis Partial Least Square (PLS)}

Pada pengujian ini juga dilakukan estimasi koefisien - koefisien jalur yang mengidentifikasikan kekuatan dari hubungan antara variabel independen dan variabel dependen. Model pengukuran terdiri dari hubungan antara item - item variabel dapat diobservasi dan konstruk laten yang diukur dengan item - item tersebut.

\section{Evaluasi Model Pengukuran/ Measurement (Outer Model)}

Terdapat tiga kriteria di dalam penggunaan teknik analisa data dengan SmartPLS untuk menilai outer model yaitu Convergent Validity, Discriminant Validity dan Composite Reliability. Convergent validity dari model pengukuran dengan refleksif indikator dinilai berdasarkan korelasi antara item score/componentscore yang diestimasi dengan Soflware PLS. Ukuran refleksif individual dikatakan tinggi jika berkorelasi lebih dari 0,70 dengan konstruk yang diukur. Namun menurut Chin, 1998 (dalam Ghozali, 2006) untuk penelitian tahap awal dari pengembangan skala pengukuran nilai loading 0,5 sampai 0,6 dianggap cukup memadai. Dalam penelitian ini akan digunakan batas loading factor sebesar 0,50 .

\section{Validitas Konvergen (Convergent Validity)}

Validitas konvergen dari model pengukuran dengan refleksif indikator dinilai berdasarkan korelasi antara skor item atau component score dengan skor variabel laten atau construct score yang dihitung dengan PLS. Nilai loading factor di atas 0,7 dikatakan ideal dan valid. Tetapi, nilai loading factor di atas 0,5 juga masih dapat diterima asalkan nilainya tidak dibawah 0,5. Berikut disajikan hasil dari outer loading untuk setiap indikator - indikator yang dimiliki oleh tiap - tiap variabel laten eksogen dan endogen dalam 2 model penelitian yang didapat dari olah data menggunakan SmartPLS pada tabel 7 berikut

Nilai faktor loading $>0,7$ dapat dikatakan valid, akan tetapi rule of thumbs intrepretasi nilai faktor loading $>0,5$ dapat dikatakan valid. Dari tabel ini, diketahui bahwa semua nilai faktor loading dari indikator Kepemimpinan Transformasional (X1), Kepemimpinan Transaksional (X2), dan Iklim Organisasi (Y) dan Organizational citizenship behavior (Y2) lebih besar dari 0,60. Hal ini menunjukan bahwa indikator - indikator tersebut valid.

\section{Validitas Diskriminan (Discriminant Validity)}

Discriminant validity dari model pengukuran dinilai berdasarkan pengukuran cross loading dengan konstruk. Jika korelasi konstruk dengan pokok pengukuran (setiap indikatornya) lebih besar daripada ukuran konstruk lainnya, maka konstruk laten memprediksi indikatornya lebih baik daripada konstruk lainnya. Hasil pengujian discriminant validity diperoleh sebagai berikut :

Berdasarkan nilai cross loading, dapat diketahui bahwa semua indikator yang menyusun masing-masing variabel dalam penelitian ini (nilai yang dicetak tebal) telah memenuhi discriminant validity karena memiliki nilai outer loading terbesar untuk variabel yang dibentuknya dan tidak pada variabel yang lain. Dengan demikian semua indikator di tiap variabel dalam penelitian ini telah memenuhi discriminant validity.

\section{Composite Reliability}

Pengujian selanjutnya untuk menganalisis outer model adalah dengan melihat reliabilitas konstruk variabel laten yang diukur dengan dua kriteria yaitu composite reliability dan cronbach alpha dari blok indikator yang mengukur konstruk. Konstruk dinyatakan reliabel jika nilai composite reliability maupun nilai cronbach alpha diatas 0,70. Berikut hasil output composite reliability dan cronbach alpha:

Goodness of Fit

\begin{tabular}{cccc}
\hline Konstruk & AVE & Composite Reliability & Cronbachs Alpha \\
\hline $\mathrm{X} 1$ & 0.5428 & 0.9338 & 0.9220 \\
\hline $\mathrm{X} 2$ & 0.6014 & 0.9000 & 0.8659 \\
\hline $\mathrm{Y} 1$ & 0.5598 & 0.9501 & 0.9435 \\
\hline $\mathrm{Y} 2$ & 0.6401 & 0.9726 & 0.9703 \\
\hline
\end{tabular}

Sumber: Pengolahan Data Dengan PLS, 2016 
Nilai AVE untuk keempat konstruk tersebut lebih besar dari 0,5 sehingga dapat disimpulkan bahwa evaluasi pengukuran model memiliki discriminant validity yang baik.

Disamping uji validitas konstruk, dilakukan juga uji reliabilitas konstruk yang diukur dengan uji criteria yaitu composite reliability dan cronbach alpha dari blok indikator yang mengukur konstruk. Konstruk yang dinyatakan reliable jika nilai composite reliability maupun cronbach alpha di atas 0.70. Jadi dapat disimpulkan bahwa konstruk memiliki reliabilitas yang baik.

\section{Evaluasi Model Struktural / Structural (Inner Model)}

Pengujian inner model atau model struktural dilakukan untuk melihat hubungan antara konstruk nilai signifikansi dan $R$-square dari model penelitian. Model struktural dievaluasi dengan menggunakan $R$-square untuk konstruk dependen uji t serta signifikansi dari koefisien parameter jalur struktural.

\section{R-Square $\left(\mathbf{R}^{2}\right)$}

Nilai R-Square

\begin{tabular}{cl}
\hline Variabel & R Square \\
\hline $\mathrm{Z}$ & 0.6391 \\
\hline $\mathrm{Y}$ & 0.6576
\end{tabular}

Sumber: Pengolahan data dengan PLS, 2016

Pada prinsipnya penelitian ini menggunakan 2 buah variabel yang dipengaruhi oleh variabel lainnya yaitu variabel Iklim Organisasi $(Z)$ yang dipengaruhi oleh variabel Kepemimpinan Transformasional (X1), Kepemimpinan Transaksional (X2). Demikian juga dengan variabel Organizational citizenship behavior (Y2) yang dipengaruhi oleh variabel Kepemimpinan Transformasional (X1), Kepemimpinan Transaksional (X2), dan variabel Iklim Organisasi (Z).

Tabel 10 menunjukan nilai $\mathrm{R}$-square untuk variabel Iklim Organisasi diperoleh sebesar 0,6391. Nilai R-square tersebut menunjukkan bahwa 63,91\% variabel Iklim Organisasi $(Z)$ dapat dipengaruhi oleh variabel Kepemimpinan Transformasional (X1) dan Kepemimpinan Transaksional (X2). sedangkan sisanya $36,09 \%$ di pengaruhi oleh variabel lain di luar yang diteliti. Tabel 10 menunjukkan nilai R-square organizational citizenship behavior sebesar 0,6576 menunjukkan variabel Organizational citizenship behavior (Y) dipengaruhi oleh variabel Kepemimpinan
Transformasional (X1), Kepemimpinan Transaksional (X2) dan Iklim Organisasi (Z) sebesar $65,76 \%$ sedangkan sisanya $34,24 \%$ di pengaruhi oleh variabel lain di luar yang diteliti.

\section{Predictive Relevance $\left(\mathrm{Q}^{2}\right)$}

$Q$-Square predictive relevance untuk model struktural, megukur seberapa baik nilai konservasi dihasilkan oleh model dan juga estimasi parameternya. Besaran $\mathrm{Q}^{2}$ memiliki nilai dengan rentang $0<\mathrm{Q}^{2}<1$, dimana semakin mendekati 1 berarti model semakin baik. Besaran $Q^{2}$ ini setara dengan koefisien determinasi total pada analisis jalur (path analysis). Berdasarkan tabel 5.13 maka perhitungan predictive relevance adalah sebagai berikut.

Nilai $Q^{2}=1-\left(1-\mathrm{R}^{2}\right) \times\left(1-\mathrm{R}^{2}\right)$

Nilai $Q^{2}=1-(1-0.6391) \times(1-0.6576)$

$$
=0.8764
$$

Keterangan :

$$
\begin{array}{ll}
\mathrm{Q}^{2} & \text { : nilai Predictive Relevance } \\
\mathrm{R}_{1}{ }^{2} & \begin{array}{l}
\text { : nilai } R \text {-Square variabel Iklim } \\
\text { Organisasi }
\end{array} \\
\mathrm{R}_{2}{ }^{2} & \begin{array}{l}
\text { : nilai } R \text {-Square variabel } \\
\text { Organizational citizenship behavior }
\end{array}
\end{array}
$$

Dari hasil perhitungan tersebut diketahui nilai $\mathrm{Q}^{2}$ sebesar 0.8764 , artinya adalah besarnya keragaman data dari penelitian yang dapat dijelaskan oleh model struktural yang dirancang adalah sebesar $87,64 \%$, sedangkan sisanya $12,36 \%$ dijelaskan oleh faktor lain diluar model. Berdasarkan hasil ini dapat dikatan model struktural pada penelitian ini cukup baik karena mendekati nilai 1 .

\section{Pengujian Hipotesis Penelitian}

Dalam hal ini dilakukan metode bootstrap terhadap sampel. Pengujian dengan bootstrap juga dimaksudkan untuk meminimalkan masalah ketidaknormalan data penelitian. Hasil pengujian dengan bootstrapping dari analisis PLS adalah sebagai berikut :

\section{Path Coefficient (Mean, STDEV, T-Values)}

\begin{tabular}{ccccc}
\hline Variabel & $\begin{array}{c}\text { Original } \\
\text { Sample } \\
(\mathbf{O})\end{array}$ & $\begin{array}{c}\text { Standard } \\
\text { Deviation } \\
\text { (STDEV) }\end{array}$ & $\begin{array}{c}\text { T Statistics } \\
(\mid \mathbf{O} / \text { STERR|) }\end{array}$ & $\begin{array}{c}\text { p- } \\
\text { Value }\end{array}$ \\
\hline $\mathrm{X} 1$-> Z & 0.3902 & 0.0823 & 4.7386 & 0.000 \\
\hline $\mathrm{X} 2$-> Z & 0.4668 & 0.0851 & 5.4826 & 0.000 \\
\hline $\mathrm{X} 1$-> Y & 0.3212 & 0.1025 & 3.1326 & 0.002 \\
\hline $\mathrm{X} 2$-> Y & 0.2584 & 0.0979 & 2.6397 & 0.010 \\
\hline $\mathrm{Z} \mathrm{->} \mathrm{Y}$ & 0.3112 & 0.0989 & 3.1449 & 0.000 \\
\hline
\end{tabular}

Sumber: Pengolahan Data Dengan PLS, 2017 
Persamaan struktural yang didapat adalah :

$$
\begin{aligned}
& Z=0,3902 X_{1}+0.4668 X_{2} \\
& Y=0,3212 X_{1}+0.2584 X_{2}+0.3112 Z
\end{aligned}
$$

Signifikansi parameter yang diestimasi memberikan informasi yang sangat berguna mengenai hubungan antara variabel - variabel penelitian. Dasar yang digunakan dalam menguji hipotesis adalah nilai yang terdapat pada output result for inner weight. Pengujian hipotesis dapat dilakukan dengan membandingkan t-statistik dengan t-tabel. Ttabel dapat diperoleh dari 130 responden yang pada akhirnya didapatkan t-tabel sebesar 1,960. Tabel 11 memberikan output estimasi untuk pengujian model struktural.

\begin{tabular}{|c|c|c|c|}
\hline Hipotesis & $\begin{array}{c}\mathrm{t}- \\
\text { Statistik } \\
\end{array}$ & $\begin{array}{c}\mathrm{t}- \\
\text { Tabel }\end{array}$ & Keterang \\
\hline $\begin{array}{l}\text { Hipotesis : } 1 \text { Kepemimpinan } \\
\text { Transformasional } \rightarrow \text { Iklim } \\
\text { Organisasi }\end{array}$ & 4.7386 & 1,960 & $\begin{array}{l}\text { H1 di } \\
\text { Terima }\end{array}$ \\
\hline $\begin{array}{l}\text { Hipotesis : } 1 \text { Kepemimpinan } \\
\text { Transaksional } \rightarrow \text { Iklim } \\
\text { Organisasi }\end{array}$ & 5.4826 & 1,960 & $\begin{array}{l}\mathrm{H} 2 \mathrm{di} \\
\text { Terima }\end{array}$ \\
\hline $\begin{array}{l}\text { Hipotesis : } 1 \text { Kepemimpinan } \\
\text { Transformasional } \rightarrow \text { OCB }\end{array}$ & 3.1326 & 1,960 & $\begin{array}{c}\mathrm{H} 3 \mathrm{di} \\
\text { Terima }\end{array}$ \\
\hline $\begin{array}{l}\text { Hipotesis : } 1 \text { Kepemimpinan } \\
\text { Transformasional } \rightarrow \text { OCB }\end{array}$ & 2.6397 & 1,960 & $\begin{array}{c}\text { H4 di } \\
\text { Terima }\end{array}$ \\
\hline $\begin{array}{l}\text { Hipotesis : } 1 \text { Iklim Organisasi } \\
\rightarrow \text { OCB }\end{array}$ & 3.1449 & 1,960 & $\begin{array}{c}\mathrm{H} 5 \mathrm{di} \\
\text { Terima }\end{array}$ \\
\hline $\begin{array}{l}\text { Hipotesis : } 1 \text { Kepemimpinan } \\
\text { Transformasional } \rightarrow \text { Iklim } \\
\text { Organisasi } \rightarrow \text { OCB }\end{array}$ & 2.5820 & 1,960 & $\begin{array}{l}\text { H6 di } \\
\text { Terima }\end{array}$ \\
\hline $\begin{array}{l}\text { Hipotesis : } 1 \text { Kepemimpinan } \\
\text { Transaksional } \rightarrow \text { Iklim } \\
\text { Organisasi } \rightarrow \text { OCB }\end{array}$ & 2.6960 & 1,960 & $\begin{array}{l}\text { H7 di } \\
\text { Terima }\end{array}$ \\
\hline
\end{tabular}

Hasil Uji Hipotesis

Sumber: Data Primer Diolah, 2017

Pengaruh tidak Langsung

\begin{tabular}{ccccccccc}
\hline $\begin{array}{l}\text { Vara } \\
\text { ibel }\end{array}$ & \multicolumn{2}{c}{$\begin{array}{l}\text { Koefisien } \\
\text { Langsung }\end{array}$} & \multicolumn{2}{c}{$\begin{array}{c}\text { standar } \\
\text { error }\end{array}$} & $\begin{array}{c}\text { Koefi } \\
\text { sien } \\
\text { TL }\end{array}$ & $\begin{array}{c}\text { se } \\
\text { Ga } \\
\text { b }\end{array}$ & $\begin{array}{c}\text { t } \\
\text { Hit } \\
\text { ung }\end{array}$ & $\begin{array}{c}\text { p- } \\
\text { Val } \\
\text { ue }\end{array}$ \\
\hline $\mathrm{X} 1$, & 0.3 & 0.3 & 0.0 & 0.0 & 0.121 & 0.0 & 2.58 & 0.0 \\
$\mathrm{Z}, \mathrm{Y}$ & 902 & 112 & 823 & 989 & & 47 & 20 & 11 \\
\hline $\mathrm{X} 2$, & 0.4 & 0.3 & 0.0 & 0.0 & \multirow{2}{*}{0.145} & 0.0 & 2.69 & 0.0 \\
$\mathrm{Z}, \mathrm{Y}$ & 668 & 112 & 851 & 989 & & 54 & 60 & 08 \\
\hline
\end{tabular}

Sumber: Data diolah, 2017

\section{Pembahasan Hipotesis 1}

Hipotesis 1 menyatakan bahwa kepemimpinan transformasional berpengaruh signifikan secara langsung terhadap iklim organisasi. Hasil penelitian ini menunjukkan bahwa pada RSUD Genteng Kabupaten Banyuwangi kepemimpinan transformasional berpengaruh terhadap iklim organisasi. Hasil penelitian ini sejalan dengan Lee (2013) yang menyatakan bahwa kepemimpinan transformasional secara signifikan berdampak pada iklim organisasi. Berdasarkan nilai loading factor, indikator pengaruh ideal mempunyai nilai loading factor yang tertinggi berarti bahwa hal yang paling berperan dalam kepemimpinan transformasional pada RSUD Genteng Kabupaten Banyuwangi adalah pimpinan memberikan visi dan misi, memunculkan rasa bangga, serta mendapatkan respek dan kepercayaan bawahan.

\section{Pembahasan Hipotesis 2}

Hipotesis 2 menyatakan bahwa kepemimpinan transaksional berpengaruh signifikan secara langsung terhadap iklim organisasi. Hasil penelitian ini menunjukkan bahwa pada RSUD Genteng Kabupaten Banyuwangi kepemimpinan transaksional berpengaruh terhadap iklim organisasi. Hasil penelitian ini sejalan dengan Koene et al. (2002) yang menyatakan bahwa hubungan kepemimpinan transaksional dengan iklim organisasi dan kinerja organisasi memiliki pengaurh yang positif signifikan Berdasarkan nilai loading factor, indikator eksepsi manajemen aktif mempunyai nilai loading factor yang tertinggi berarti bahwa hal yang paling berperan dalam kepemimpinan transaksional pada RSUD Genteng Kabupaten Banyuwangi adalah pimpinan senantiasa melakaukan pengawasan terhadap seluruh unitunit organisasi dan mencari penyimpangan yang terjadi terhadap aturan dan standar, serta mengambil tindakan korektif.

\section{Pembahasan Hipotesis 3}

Hipotesis 3 menyatakan bahwa kepemimpinan transformasional berpengaruh signifikan secara langsung terhadap organizational citizenship behavior (OCB). Hasil penelitian ini menunjukkan bahwa pada RSUD Genteng Kabupaten Banyuwangi kepemimpinan transformasional berpengaruh signifikan terhadap OCB. Hal ini sejalan dengan penelitian yang dilakukan oleh Podsakoff et al., (1990 dalam Lamidi, 2008) bahwa "perilaku kepemimpinan mempengaruhi bawahan untuk menghasilkan kinerja melebihi apa yang seharusnya atau melebihi level minimum yang dipersyaratkan organisasi”. Berdasarkan nilai loading factor, indikator pengaruh ideal mempunyai nilai loading factor yang tertinggi berarti bahwa hal yang paling berperan dalam kepemimpinan transformasional pada RSUD Genteng Kabupaten Banyuwangi adalah pimpinan memberikan visi dan misi, memunculkan rasa bangga, serta mendapatkan respek dan kepercayaan bawahan. 


\section{Pembahasan Hipotesis 4}

Hipotesis 4 menyatakan bahwa kepemimpinan transaksional berpengaruh signifikan secara langsung terhadap organizational citizenship behavior (OCB). Hasil penelitian ini menunjukkan bahwa pada RSUD Genteng Kabupaten Banyuwangi kepemimpinan transaksional berpengaruh signifikan terhadap OCB. Hal ini berarti bahwa praktik kepemimpinan transaksional yang baik, yaitu penghargaan kontingensi, eksepsi manajemen aktif dan pasif merupakan cara yang efektif untuk meningkatkan OCB pegawai. Peran pimpinan sangat berpengaruh terhadap tinggi rendahnya kinerja pegawai. Agar pegawai dapat lebih meningkatkan volume dan mutu pekerjaan yang menjadi tanggung jawab mereka, maka kewajiban seorang pimpinan dengan gaya kepemimpinan transaksional lebih bertanggungjawab dalam memberikan apresiasi dalam bentuk apapun kepada para pegawai. Seorang pimpinan tidak hanya memberi keteladanan, tetapi juga mampu memberikan reward, sehingga bawahan dapat menunjukkan kesadaran dalam perilaku kerja dengan bukti bahwa mereka melakukan pekerjaannya melebihi standar yang ditetapkan oleh organisasi. Dengan adanya kepemimpinan transaksional yang diterapkan dalam suatu organisasi, maka hal itu bisa memacu pegawai untuk meningkatkan perilaku kerja mereka.

\section{Pembahasan Hipotesis 5}

Hipotesis 5 menyatakan bahwa iklim organisasi berpengaruh signifikan secara langsung terhadap organizational citizenship behavior (OCB). Hasil penelitian ini menunjukkan bahwa pada RSUD Genteng Kabupaten Banyuwangi dalam iklim organisasi berpengaruh terhadap OCB. Hal ini berarti bahwa praktik iklim organisasi yang kondusif, yaitu tanggungjawab, identitas, kehangatan, dukungan, dan konflik merupakan cara yang paling efektif untuk menciptakan iklim organisasi yang kondusif. Berdasarkan nilai loading factor, iIndikator dengan nilai loading factor tertinggi pada variabel iklim organisasi adalah dukungan yang berarti bahwa hal yang paling berperan dalam iklim organisasi pada RSUD Genteng Kabupaten Banyuwangi adalah terkait dengan dukungan dan hubungan antar sesama rekan kerja yaitu perasaan saling menolong antara manajer dan karyawan, lebih ditekankan pada dukungan yang saling membutuhkan antara atasan dan bawahan.

\section{Pembahasan Hipotesis 6}

Hipotesis 6 menyatakan bahwa kepemimpinan transformasional berpengaruh signifikan secara tidak langsung terhadap organizational citizenship behavior (OCB) melalui iklim organisasi. Hasil penelitian ini menunjukkan bahwa pada RSUD Genteng Kabupaten Banyuwangi kepemimpinan transformasional berpengaruh signifikan terhadap OCB melalui variabel iklim organisasi. Hasil analisis menunjukkan bahwa peran kepemimpinan yang menjadi teladan didalam organisasi dapat mempengaruhi kondisi iklim organisasi (tanggungjawab, identitas, kehangatan, dukungan, dan konflik) dan juga perilaku ekstra peran pegawai. Semakin baik persepsi pegawai terhadap kepemimpinan transformasional maka persepsi pegawai terhadap iklim organisasi juga semakin baik sehingga dapat meningkatkan OCB pegawai.

\section{Pembahasan Hipotesis 7}

Hipotesis 7 menyatakan bahwa kepemimpinan transaksional berpengaruh signifikan secara tidak langsung terhadap organizational citizenship behavior (OCB) melalui iklim organisasi. Hasil penelitian ini menunjukkan bahwa pada RSUD Genteng Kabupaten Banyuwangi kepemimpinan transaksional berpengaruh signifikan terhadap OCB melalui variabel iklim organisasi. Hal ini menunjukkan bahwa tidak cukup hanya dengan Kepemimpinan Transaksional yang baik yang telah diterapkan pada RSUD Genteng Kabupaten Banyuwangi maka pegawai akan loyal. Dengan kata lain bahwa, upaya dalam meningkatkan iklim organisasi artinya iklim organisasi yang terjaga dengan baik dan dapat diandalkan untuk dapat memberikan suasana kerja yang diharapkan pegawai juga dapat berepengaruh besar terhadap peningkatan OCB pegawai. Keterpaduan antara pemimpin transaksional dengan iklim organisasi yang kondusif maka hal tersebut mampu menciptakan OCB pegawai.

\section{KESIMPULAN DAN SARAN Kesimpulan}

Berdasarkan hasil penelitian, maka dalam rangka menjawab tujuan penelitian dapat diambil kesimpulan penelitian sebagai berikut:

1. Pada RSUD Genteng Kabupaten Banyuwangi, praktik Kepemimpinan Transformasional yang diterapkan, yaitu 
dengan pengaruh ideal/kharisma, motivasi inspirasi, rangsangan intelektual, pertimbangan individu, secara efektif dapat membentuk Iklim Organisasi yang kondusif.

2. Pada RSUD Genteng Kabupaten Banyuwangi, praktik Kepemimpinan Transaksional yang diterapkan, yaitu dengan penghargaan kontingensi, eksepsi manajemen aktif, dan juga eksepsi manajemen pasif, secara efektif dapat menciptakan Iklim Organisasi yang baik.

3. Pada RSUD Genteng Kabupaten Banyuwangi, kondisi Iklim Organisasi yang kondusif yang diterapkan, yaitu dengan tanggungjawab, identitas, kehangatan, dukungan dan konflik, secara efektif dapat meningkatkan perilaku ekstra peran (OCB) pegawai.

4. Pada RSUD Genteng Kabupaten Banyuwangi, praktik Kepemimpinan Transformasional yang diterapkan, yaitu dengan pengaruh ideal/kharisma, motivasi inspirasi, rangsangan intelektual, pertimbangan individu, secara efektif dapat meningkatkan perilaku ekstra peran (OCB) pegawai.

5. Pada RSUD Genteng Kabupaten Banyuwangi, praktik Kepemimpinan Transaksional yang diterapkan, yaitu dengan penghargaan kontingensi, eksepsi manajemen aktif, dan juga eksepsi manajemen pasif, secara efektif dapat dapat meningkatkan perilaku ekstra peran (OCB) pegawai.

6. Pada RSUD Genteng Kabupaten Banyuwangi, Iklim Organisasi yang baik dan kondusif, secara efektif dapat meningkatkan perilaku ekstra peran (OCB) pegawai. Sehingga iklim organisasi mampu menjadi mediasi antara kepemimpinan transformasional dan perilaku ekstra peran (OCB) pegawai.

7. Pada RSUD Genteng Kabupaten Banyuwangi, Iklim Organisasi yang baik dan kondusif, secara efektif dapat meningkatkan perilaku ekstra peran (OCB) pegawai. Sehingga iklim organisasi mampu menjadi mediasi antara kepemimpinan transaksional dan perilaku ekstra peran (OCB) pegawai.

\section{Saran}

1. Para pengambil kebijakan dapat mempertimbangkan untuk mengadakan penilaian kinerja secara periodik terhadap pegawai secara menyeluruh dan juga evaluasi terhadap para pimpinan, hal tersebut dapat diwujudkan melalui evaluasi kinerja pegawai setiap minggu, setiap bulan, atau setiap tahun. Lebih lanjut, pada setiap akhir pelaksanaan evaluasi kinerja, pihak manajemen organisasi agar mengakui eksistensi dan prestasi kerja para pegawai atau pimpinan melalui pemilihan "stafflleader of the month" atau "stafflleader of the year" sehingga mereka merasa dihargai akan keberadaannya untuk bekerja lebih baik lagi.

2. Para pimpinan agar mengakomodir dan mencanangkan dengan baik forum diskusi informal didalam kantor yang membahas mengenai persoalan-persoalan yang terjadi, baik itu persoalan yang sudah diprediksikan maupun persoalan diluar yang dugaan, karena hal ini dapat secara cepat, efektif dan efisien, untuk mengatasi persoalan tersebut tanpa harus menunggu pelatihan secara tehnis. Organisasi dapat mewujudkan hal ini melalui memberi ruangan secara khusus dan isi ruangan tersebut dapat memadai untuk diskusi seperti, pengadaan laptop, LCD, koneksi internet, whiteboard, mamiri, dan sebagainya. Sehingga jalannya diskusi tersebut dapat berjalan dengan santai tanpa tekanan, ide-ide pegawai pun dapat mengalir dengan baik.

\section{DAFTAR PUSTAKA}

As'ad, Moch. (1998). Seri Ilmu Sumber Daya Manusia Psikologi Industri. Yogyakarta: Liberti

Avolio B. J, Zhu W, Koh W, Bhatia P., (2004). Transformational leadership and organizational commitment: Mediating role of psychological empowerment and moderating role of structural distance. Journal Organization Behavior, Vol. 25, No. 8, pp. 951-68.

Brahmana, S.S. \& Sofyandi, H. (2007). Transformational Leadership dan Organization Citizenship Behavior di Utama. Laporan Penelitian. Tidak diterbitkan.

Chen, Jui-Chen and Silverthorne, Colin. (2005). Leadership Effectiveness, Leadership Style and Employee Readiness. Leadership \& Organization Development Journal. Vol. 26, No. 4, pp. 280-288.

Cho, J., \& Dansereau, F. (2010). Are transformational leaders fair? A multilevel study of transformational 
leadership, justice perceptions, and organizational citizenship behaviors. The Leadership Quarterly, No. 21 pp. 409421.

Gibson, James L, et.al. (2000). Organisasi: Perilaku, Struktur, Proses. Edisi Kelima. Alih Bahasa Djoerban Wahid Jakarta: Erlangga.

Ghazali, Imam. (2011). Structural Equation Modeling; Metode Alternatif Dengan Partial Least Square. Edisi 3. Semarang: Universitas Diponegoro.

Hadi, Sutrisno. (1991). Analisis Butir Instrumen, Angket Tes dan Skala Nilai dengan Basica. Yogyakarta: Andi Offset.

Imran, R., \& Anis-ul-Haque, M. (2011). Mediating Effect of Organizational Climate between Transformational Leadership and Innovative Work Behaviour. Pakistan Journal of Psychological Research, Vol. 26, No. 2, pp. 183-199.

Koene , Bas A.S., et, al., (2002). Leadership effects on organizational climate and financial performance: Local leadership effect in chain organizations. The Leadership Quarterly. Vol. 13 No. 19 pp. 193-215

Lamidi. (2008). Pengaruh Kepemimpinan Transformasional terhadap Organizational Citizenship Behavior: dengan Variabel Intervening Komitmen Organisasional. Jurnal Ekonomi dan Kewirausahaan, Vol. 8, No. 1, pp. 25 - 37

Lattener, Lynch. (2003). The Relationship of Job Satisfaction with Substitution of Leadership. Jakarta: Erlangga.

Lee, Ji-Eun B. A. (2013). Does transformational leadership style influence employees' attitudes toward. International Journal of Hospitality Management, Vol. 33, pp. 282-293.

López-Domínguez, M. et al., (2013). Transformational leadership as an antecedent of change-oriented. Journal of Business Research, Vol. 66. pp. 21472152.

Luthans, F., (1998). Organizational Behavior, Seventh Edition. International Edition. New York: McGraw-Hill Companies, Inc.

Marzuki. (1986). Metodologi Riset. Penerbit: Fakultas Ekonomi UII. Yogyakarta.
Ngadiman, Eliyana, A., \& Ratmawati, D. (2013). Influence of Transformational Leadership And Organization Climate To The Work Satisfaction, Organizational Commitment And Organizational Citizenship Behavior On The Educational Personnel Of Sebelas Maret University Surakarta. Journal Educational Research International, Vol. 1, No. 1, pp. 41-66.

Organ, D.W. (1988). Organizational citizenship behavior: The good soldier syndrome. Lexington, M. A.: Lexington Books.

Podsakoff, P.M., et al., (2000). Organizational Citizenship Behaviors: A Critical Review of the Theoretical and Empirical Literature and Suggestions for Future Research, Journal of Management, Vol 26, No 3, pp. 513-563.

Prihatsanti, U., \& Dewi, K. S. (2010). Hubungan Antara Iklim Organisasi dan Organizational Citizenship Behavior (OCB) Pada Guru SD Negeri di Kecamatan Mojolaban Sukoharjo. Jurnal Psikologi Undip, Vol. 7, No. 1. Hal. 1117

Rahmi, B. M. (2013). Pengaruh Kepemimpinan Transformasional terhadap Organizational Citizenship Behavior dan Komitmen Organisasional dengan Mediasi Kepuasan Kerja. Tesis Universitas Udayana: Bali.

Rivai, V., dan Mulyadi, D. (2012). Kepemimpinan dan Perilaku Organisasi, Jakarta: Rajawali Pers.

Robbins, Stephen P. dan Timothy A. Judge. (2008). Perilaku Organisasi Edisi ke-12, Jakarta: Salemba Empat.

Sabran, dkk. (2010). Pengaruh Kepemimpinan Transformasional, Keadilan Organisasional, Kepercayaan Organisasional, Kepuasan Kerja terhadap Organizational Citizenship Behavior. Jurnal Aplikasi Manajemen, Vol. 8, No. 4, pp. 1082-1089.

Singarimbun, M. dan Efendi. (1995). Metodologi Penelitian Survey, Edisi Revisi LP3ES. Jakarta

Sugiyono. (2009). Metode Penelitian Kuantitatif Kualitatif dan $R \& D$. Alfabeta. Bandung. Toulson, P. \& Smith, M. (1994). The Relationship Between Organizational Climate and Employee Perceptions of Personnel Management Practices. Journal of Public Personnel 
Management. Vol. 23, Issue 3. (Fall). pp. 453-469.

Utami, H. N. (2012). Pengaruh Iklim Organisasi dan Organzational Citizenship Behavior Terhadap Kinerja Anggota Koperasi. Skripsi Ilmu Administrasi Universitas Brawijaya Malang.

Utomo, Kabul Wahyu. (2001). Kecenderungan kepemimpinan transaksional dan transformasional, dan hubungannya dengan organizational citizenship behavior, komitmen dan kepuasan kerja: Studi pada kantor Pemerintah Daerah tingkat II Kabupaten Kebumen Propinsi Jawa Tengah. Tesis Tidak Dipublikasikan. Program Magister Manajemen UGM Yogyakarta.

Walumbwa, Fred O., et al., (2008). Contingent reward transactional leadership, work attitudes, and organizational citizenship behavior: The role of procedural justice climate perceptions and strength. The Leadership Quarterly. Vol. 19 No. 13 pp. 251-265

Waspodo, A. A., \& Minadaniati, L. (2012). Pengaruh Kepuasan Kerja dan Iklim Organisasi Terhadap Organizational Citizenship Behavior (OCB) Karyawan Pada PT. Trubus Swadaya. Jurnal Riset Manajemen Sains Indonesia, Vol. 3, No. 1. pp. 1-16

Wirawan, (2007). Budaya dan Iklim Organisasi: Teori, Aplikasi, dan Penelitian. Jakarta: Salemba Empat

Yıldız, M. L., \& Özcan, E. D. (2014). Organizational Climate as a moderator of the Relationship between Transformational Leadership and Creativity. International Journal of Business and Management ISSN 23362197 , Vol. II (1), pp. 76-87.

YukI, Gary A. (1998). Leadership In Organization, Mc Graw Hill Book Co, Singapore. 